\begin{tabular}{|c|c|c|}
\hline & $\begin{array}{c}\text { JOURNAL } \\
\text { PENEIJTIAN PENDIDIKAN IPA }\end{array}$ & $\begin{array}{l}e-I S S N=2407-795 X \\
p-I S S N: 2460-2582\end{array}$ \\
\hline PPI & $\underline{\text { http://jurnal.unram.ac.id/index.php/jpp-ipa }}$ & $\begin{array}{l}\text { Vol 1, No, } 2 \\
\text { Juli } 2015\end{array}$ \\
\hline
\end{tabular}

\title{
PENINGKATAN KETERAMPILAN BERPIKIR KRITIS MELALUI MODEL PEMBELAJARAN DISCOVERY LEARNING
}

\author{
Devi Qurniati ${ }^{1}$, Yayuk Andayani ${ }^{2}$, Muntari $^{2}$ \\ Program Studi Magister Pendidikan IPA Program Pascasarjana Universitas Mataram ${ }^{123}$ \\ chemistry_devi@yahoo.com
}

\begin{tabular}{ll}
\hline Key Words & Abstract \\
\cline { 2 - 3 } $\begin{array}{l}\text { Discovery } \\
\text { learning, } \\
\text { critical }\end{array}$ & The importance of critical thinking skills for students in the study of chemistry, \\
thinking skills & is necessary to appropriate learning models that can involve students \\
& thinking skills. One model that can be applied is discovery learning model \\
& learning. The purpose of this study was to determine the increase in critical \\
& thinking skills of students learning through discovery learning. This study was \\
an experimental study design with nonequivalent pretest-Posttes Control \\
Group Design. The subjects of the study involves two classes of experimental \\
class and control class. Data collection instruments in the form of test critical \\
thinking skills in the form of matter description. Statistical testing using \\
independent sample t-test were previously tested for normality, homogeneity \\
test at the 0.05 significance level. The results showed no difference in the \\
increase in critical thinking skills in each of the indicators of critical thinking \\
skills
\end{tabular}

\begin{tabular}{ll}
\hline Kata Kunci & Abstrak \\
\cline { 2 - 3 } $\begin{array}{l}\text { Discovery } \\
\text { learning, }\end{array}$ & Pentingnya kemampuan berpikir kritis bagi siswa dalam mempelajari kimia, \\
Keterampilan & maka diperlukan model pembelajaran yang tepat yang dapat melibatkan siswa \\
berpikir kritis & menara langsung dalam pembelajaran sehingga menjadikan siswa aktif dan \\
& diterapkan adalah model pembelajaran discovery learning. Tujuan penelitian \\
& ini adalah untuk mengetahui peningkatan keterampilan berpikir kritis siswa \\
& melaui pembelajaran discovery learning. Penelitian ini merupakan penelitian \\
& eksperimen dengan desain nonequivalent Pretest-Posttes Control Group \\
& Design. Subyek penelitian melibatkan dua kelas yaitu kelas eksperimen dan \\
& kelas kontrol. Instrumen pengumpulan data berupa soal tes kemampuan \\
& berpikir kritis dalam bentuk soal uraian. Pengujian statistik dengan \\
& menggunakan independent sample t-test yang sebelumnya diuji normalitas, uji \\
& homogenitas pada taraf signifikansi 0,05. Hasil penelitian menunjukkan tidak \\
& ada perbedaan peningkatan keterampilan berpikir kritis pada masing-masing \\
& indikator keterampilan berpikir kritis.
\end{tabular}




\section{PENDAHULUAN}

Pembelajaran kimia akan lebih bermakna jika siswa terlibat aktif dalam pembelajaran. Siswa dapat terlibat aktif dalam pembelajaran jika siswa melakukan pengamatan langsung. Menurut Hasruddin (2009), proses belajar akan lebih banyak melibatkan siswa melalui kegiatan penemuan karena dalam kegiatan penemuan, siswa melakukan observasi sehingga dapat meningkatkan kemampuan berpikir kritis siswa. Selain itu, pembelajaran yang aktif memiliki efek positif terhadap peningkatan keterampilan berpikir kritis siswa (Peter, 2012). Keterlibatkan siswa secara aktif melakukan eksplorasi materi pelajaran, mengkonstruksi sendiri ide-ide yang didapat dari hasil pengamatan dan diskusi, diharapkan siswa dapat menguasai materi dengan baik dan meningkatkan keterampilan berpikir (Ardiyanti, 2013).

Menurut Chaffee (Suriadi, 2006), berpikir kritis adalah berpikir untuk menyelidiki secara sistematis proses berpikir itu sendiri. Maksudnya, tidak hanya memikirkan dengan sengaja, tetapi juga meneliti bagaimana kita dan orang lain menggunakan bukti dan logika. Berpikir kritis menjadikan seseorang berpikir secara terorganisasi mengenai proses berpikir diri sendiri dan proses berpikir orang lain yang akan membekali anak untuk sebaik mungkin menghadapi informasi yang mereka dengar dan baca, kejadian yang mereka alami, dan keputusan yang mereka buat setiap hari. Hal ini berarti dengan berpikir kritis memungkinkan anak menganalisis pemikiran sendiri untuk memastikan bahwa ia telah menemukan pilihan dan menarik kesimpulan cerdas.

Berpikir kritis adalah berpikir yang masuk akal dan reflektif yang berfokus untuk menentukan apa yang harus dipercaya atau dilakukan (Ennis,1985). Masuk akal berarti kemampuan berpikir yang berusaha menghubungkan fakta-fakta yang diketahui menjadi suatu kesimpulan, sedangkan reflektif berarti mempertimbangkan secara aktif, tekun dan hati-hati terhadap segala alternatif sebelum mengambil keputusan. Terdapat 5 aspek keterampilan berpikir yang diuraikan menjadi 12 indikator. Indikator tersebut masih dapat diuraikan lagi menjadi sub indikator berpikir kritis diantaranya: 1) merumuskan pertanyaan, 2) memberikan contoh, 3) menjawab pertanyaan 'mengapa', 4) melaporkan hasil observasi, 5) menggeneralisasikan data, tabel dan grafik, 6) memberikan kesimpulan,7) mempertimbangkan alternatif jawaban.

Ennis dan Norris (Nitko, 1996) membagi komponen kemampuan penguasaan pengetahuan menjadi lima keterampilan, yang selanjutnya disebut keterampilan berpikir kritis, yaitu: 
1) Klarifikasi elementer (elementary clarificat-ion), meliputi: memfokuskan pertanyaan, menganalisis argumen, bertanya dan menjawab pertanyaan yang membutuhkan penjelasan atau tantangan.

2) Dukungan dasar (basic support), meliputi: mempertimbangkan kredibilitas sumber dan melakukan pertimbangan observasi.

3) Penarikan kesimpulan (inference), meliputi: melakukan dan mempertimbangkan deduksi, melakukan dan mempertimbangkan induksi, melakukan dan mempertimbangkan nilai keputusan.

4) Klarifikasi lanjut (advanced clarification), meliputi: mengidentifikasi istilah dan mem-pertimbangkan definisi, dan mengidentifikasi asumsi.

5) Strategi dan taktik (strategies and tactics), meliputi: menentukan suatu tindakan, berinteraksi dengan orang lain.

Setiap orang dapat belajar untuk berpikir kritis karena otak manusia secara konstan ber-usaha memahami pengalaman. Pencariannya yang terus menerus akan makna, otak dengan tangkas menghubungkan ide abstrak dengan konteksnya di dunia nyata (Lambertus, 2009). Menurut Wahyuni, keterampilan berpikir kritis bukan merupakan suatu keterampilan yang dapat berkembang dengan sendirinya seiring dengan perkembangan fisik manusia. Keterampilan ini harus dilatih melalui pemberian stimulus yang menuntut seseorang untuk berpikir kritis. Sekolah sebagai suatu institusi penyelenggara pendidikan memiliki tanggung jawab untuk membantu siswanya mengembangkan keterampilan berpikir kritis. Dalam Peraturan Menteri Pendidikan Nasional No. 23 tahun 2006 tentang Standar Kompetensi Lulusan untuk Satuan Pendidikan Dasar dan Menengah terdapat beberapa kompetensi yang terkait dengan penguasaan keterampilan berpikir kritis, yaitu bahwa lulusan harus dapat:

a) Membangun, menggunakan dan menerapkan informasi tentang lingkungan sekitar secara logis, kritis, dan kreatif,

b) Menunjukkan kemampuan berpikir logis, kritis, kreatif, dan inovatif,

c) Menunjukkan rasa keingintahuan yang tinggi dan menyadari potensinya,

d) Menunjukkan kemampuan memecahkan masalah,

e) Menunjukkan kemampuan mengenali gejala alam dan sosial di lingkungan sekitar,

f) Menunjukkan kemampuan belajar secara mandiri sesuai dengan potensi yang dimilikinya. 
Menurut Sastrika (2013), mengembangkan keterampilan berpikir kritis perlu dikembangkan sedini mungkin. Berdasarkan hasil observasi di SMAN 2 Labuapi dengan menggunakan angket siswa terdapat $64,71 \%$ siswa menyatakan tidak diarahkan untuk menemukan konsep sendiri dalam pembelajaran. Sebanyak 58,82\% siswa menyatakan guru tidak mengarahkan siswa untuk melakukan observasi/pengamatan sehingga pembelajaran di kelas belum mengarah pada keterampilan berpikir kritis. Hasil angket observasi guru, penyampaian materi kimia dalam pembelajaran selama ini menggunakan model pembelajaran langsung karena model tersebut dapat mengontrol siswa. Model pembelajaran tersebut cenderung berpusat pada guru, sehingga sebagian besar siswa cenderung bersikap pasif. Hal tersebut berdampak pada hasil belajar siswa rendah yang ditunjukkan dengan nilai rata-rata ulangan semester kimia yang diperoleh siswa yaitu 54,2. Nilai rata-rata tersebut masih di bawah kriteria ketuntasan minimal (KKM) yang telah ditetapkan yaitu 70. Berdasarkan hasil observasi dapat disimpulkan bahwa siswa belum terlatih untuk berpikir kritis, sehingga keterampilan siswa dalam berpikir kritis rendah. oleh karena itu penelitian ini bertujuan untuk mengetahui peningkatan keterampilan berpikir kritis siswa pada masing-masing indikator berpikir kritis. Untuk dapat meningkatkan kemampuan berpikir kritis maka diperlukan model pembelajaran yang tepat. Salah satu model pembelajaran yang dapat diterapkan untuk meningkatkan kemampuan berpikir kritis adalah model pembelajaran discovery learning. Model pembelajaran discovery learning merupakan model pembelajaran yang memberikan kesempatan kepada siswa untuk membangun pemahamannya sendiri. Dalam model ini siswa dituntut untuk lebih kreatif, mandiri dan kreatif terhadap permasalahan yang ada (Alfieri, 2011)

\section{METODE PENELITIAN}

Jenis penelitian yang digunakan dalam penelitian ini adalah penelitian quasi eksperimental. Quasi eksperimen yaitu penelitian yang digunakan untuk mencari pengaruh perlakuan tertentu terhadap variabel-variabel yang diteliti. Peneliti menggunakan quasi eksperimen karena penelitian ini menggunakan kelompok yang secara alami telah terbentuk sebelumnya yang telah terpilih secara acak, yakni kelas XA sebagai kelas eksperimen dan kelas XB sebagai kelas kontrol.

Desain penelitian yang digunakan dalam penelitian ini adalah nonequivalent pretest-posttest control group design karena dalam desain ini terdapat dua kelompok yang masing-masing dipilih secara random dimana pada kelompok pertama disebut dengan 
kelompok eksperimen yang diberi perlakuan dengan menggunakan model pembelajaran discovery learning dan kelompok yang kedua disebut dengan kelompok yang diberikan perlakuan dengan model pembelajaran konvensional (model pembelajaran langsung). Sebelum perlakuan diberikan, kedua kelompok tersebut diberikan pretest untuk mengetahui kemampuan awal siswa terhadap materi hidrokarbon. Setelah perlakuan diberikan maka kedua kelompok tersebut diberikan posttest sebagai evaluasi hasil penerapan perlakuan.

Instrumen yang digunakan dalam mengumpulkan data adalah tes keterampilan berpikir kritis berupa soal uraian yang digunakan untuk mengukur keterampilan berpikir kritis siswa. untuk mengetahui peningkatan keterampilan berpikir kritis siswa maka dilakukan analisis $N$-gain.Gain yang dinormalisasi ( $N$-gain) dapat dihitung dengan persamaan:

$$
N-\text { gain }=\frac{S \text { post }-S \text { pre }}{S \max -S \text { pre }}
$$

(Hake dalam Fachrurazi, 2011). N-gain adalah gain yang dinormalisasi, S maks adalah skor maksimum (ideal) dari tes awal dan tes akhir, $\mathrm{S}$ post adalah skor tes akhir siswa, sedangkan $\mathrm{S}$ pre adalah skor tes awal siswa. Tinggi rendahnya $\mathrm{N}$-gain dapat diklasifikasikan sebagai berikut: (1) $\mathrm{N}$-gain $\geq 0,7$, maka $\mathrm{N}$-gain yang dihasilkan termasuk kategori tinggi; (2) jika $0,3 \leq \mathrm{N}$-gain $\leq 0,7$ maka $N$-gain yang dihasilkan termasuk kategori sedang, dan (3) jika g <0,3, maka $N$-gain yang dihasilkan termasuk kategori rendah.

\section{HASIL PENELITIAN}

Penelitian ini menganalisis pengaruh model pembelajaran discovery learning terhadap keterampilan berpikir kritis dalam setiap indikator keterampilan berpikir kritis yaitu memfokuskan pertanyaan, mengobservasi dan mempertimbangkan laporan observasi, menentukan suatu tindakan, menginduksi dan mengidentifikasi asumsi.

Perolehan nilai pretest dan posttest keterampilan berpikir kritis setiap indikator pada kelas eksperimen dan kelas kontrol terdapat pada Tabel 1.

Tabel 1. Data Nilai Pretest dan Posttest Keterampilan Berpikir Kritis setiap Indikator

\begin{tabular}{ccccc}
\hline Indikator & \multicolumn{2}{c}{ Pretest } & \multicolumn{2}{c}{ Posttest } \\
\cline { 2 - 5 } KBK & Eksperimen & Kontrol & Eksperimen & Kontrol \\
\hline MP & 11,78 & 18,26 & 40,85 & 42,06 \\
MLO & 21,05 & 30,55 & 71,93 & 75 \\
MST & 16,96 & 17,13 & 32,16 & 34,26 \\
M & 10,53 & 20,56 & 28,77 & 39,45 \\
MA & 9,47 & 12,22 & 28,77 & 22,78 \\
\hline
\end{tabular}


Ket:

MP : Memfokuskan pertanyaan

MLO : Mengobservasi dan mempertimbangkan laporan observasi

MST : Menentukan suatu tindakan

M : Menginduksi

MA : Mengidentifikasi asumsi

Data pretest keterampilan berpikir kritis pada masing-masing indikator yang tidak berdistribusi normal maka uji hipotesis menggunakan uji statistik Mann Whitney. Hasil uji statistik Mann Whitney terdapat pada Tabel 2

Tabel 2. Hasil analisis data pretest pada setiap indikator

\begin{tabular}{clll} 
Indikator KBK & Uji Statistik & Sig & Keputusan \\
\hline MP & Mann Whitney U-Test & 0,009 & Ho ditolak \\
MLO & Mann Whitney U-Test & 0,082 & Ho diterima \\
MST & Mann Whitney U-Test & 0,900 & Ho diterima \\
M & Mann Whitney U-Test & 0,002 & Ho ditolak \\
MA & Mann Whitney U-Test & 0,134 & Ho diterima \\
\hline
\end{tabular}

Nilai $\mathrm{N}$-Gain keterampilan berpikir kritis masing-masing indikator menunjukkan peningkatan keterampilan berpikir kritis siswa pada tiap indikator keterampilan berpikir kritis. Nilai N-Gain tiap indikator keterampilan berpikir kritis terdapat pada Tabel 3.

Tabel 3. Data Nilai N-Gain Masing-masing Indikator Keterampilan Berpikir Kritis

\begin{tabular}{ccc}
\hline Indikator KBK & \multicolumn{2}{c}{ N-Gain } \\
\cline { 2 - 3 } & Eksperimen & Kontrol \\
\hline MP & 0,33 & 0,29 \\
MLO & 0,61 & 0,63 \\
MST & 0,18 & 0,21 \\
M & 0,2 & 0,23 \\
MA & 0,21 & 0,12 \\
\hline
\end{tabular}

Selanjutnya untuk mengetahui signifikansi perbedaan peningkatan nilai kedua kelas tersebut dilakukan uji hipotesis dengan menggunakan Independent sample T-Test jika data terdistribusi normal dan homogen dengan Mann Whitney U-test jika data data tidak terdistribusi normal dan homogen.

Hasil uji beda nilai $N$-Gain pada setiap indikator terdapat pada Tabel 4.

Tabel 4. Hasil uji beda nilai $N$-Gain Indikator Berpikir Kritis

\begin{tabular}{clll}
\hline Indikator KBK & Uji Statistik & Sig & Keputusan \\
\hline MP & Independent Sample T-Test & 0,518 & Ho diterima \\
MLO & Mann Whitney U-Test & 0,875 & Ho diterima \\
MST & Mann Whitney U - Test & 0,319 & Ho diterima \\
M & Mann Whitney U-Test & 0,515 & Ho diterima \\
MA & Independent Sample T-Test & 0,061 & Ho diterima \\
\hline
\end{tabular}




\section{PEMBAHASAN}

Penelitian ini bertujuan untuk mngetahui pengaruh model pembelajaran discovery learning terhadap keterampilan berpikir kritis. Keterampilan berpikir kritis siswa dalam penelitian ini diukur menggunakan lima indikator yang mengacu pada indikator berpikir kritis yang dikemukakan oleh Robert Ennis, yaitu memfokuskan pertanyaan, mengobservasi dan mempertimbangkan laporan observasi, menentukan suatu tindakan, menginduksi, dan mengidentifikasi asumsi (Ennis, 1985). Adapun pembahasan hasil penelitian secara rinci antara lain:

\section{Memfokuskan Pertanyaan}

Memfokuskan pertanyaan merupakan salah satu indikator keterampilan berpikir kritis, dimana indikator tersebut termasuk kedalam kelompok memberikan penjelasan sederhana. Hasil analisis data nilai posttest dan nilai pretest kedua kelas, diketahui kelas kontrol lebih unggul dari kelas eksperimen. Secara keseluruhan, kedua kelas mengalami peningkatan keterampilan berpikir kritis pada indikator memfokuskan pertanyaan. Dari hasil perhitungan, siswa kelas eksperimen memperoleh nilai rata-rata $\mathrm{N}$-Gain yang lebih tinggi dibandingkan kelas kontrol. Nilai $N$-Gain yang dihasilkan siswa kelas eksperimen masuk dalam kategori sedang sedangkan kelas kontrol dalam kategori rendah.

Setelah dilakukan uji hipotesis dengan uji-t terhadap nilai $\mathrm{N}$-Gain Keterampilan berpikir kritis pada indikator memfokuskan pertanyaan, harga signifikansi yang diperoleh sebesar 0,518 yang lebih besar dari 0,05 ( $\mathrm{p}>0.05)$. Hasil tersebut menunjukkan bahwa tidak ada perbedaan peningkatan keterampilan berpikir kritis pada indikator memfokuskan pertanyaan antara siswa kelas eksperimen dan kelas kontrol. Hal ini mengindikasikan bahwa tidak ada pengaruh model pembelajaran discovery learning terhadap peningkatan keterampilan berpikir kritis siswa pada indikator memfokuskan pertanyaan.

Hal tersebut terjadi karena Siswa lebih sering menghafal materi yang dipelajari tanpa memahami konsep. Hal ini didukung oleh pernyataan Ariyati (2010), bahwa pembelajaran di sekolah lebih banyak menghafal. Pembelajaran dengan menghafal tidak menuntut siswa untuk memberikan penjelasan sederhana terlebih dahulu sebelum memberikan inti jawaban. Faktor lain dikarenakan juga karena kemampuan awal siswa yang berbeda, dimana nilai rata-rata pretest siswa kelas kontrol pada indikator ini lebih tinggi dari kelas eksperimen. Hal ini didukung oleh pernyataan Praptiwi (2012). Kemampuan awal akan mempengaruhi berhasil atau tidaknya seorang siswa dalam 
pembelajaran. Jika kemampuan awal siswa baik, maka siswapun akan memperoleh hasil yang baik.

\section{Mengobservasi dan Mempertimbangkan Laporan Observasi}

mengobservasi dan mempertimbangkan laporan observasi merupakan salah satu indikator keterampilan berpikir kritis dimana indikator tersebut termasuk kedalam kelompok membangun keterampilan dasar. Penguasaan siswa terhadap indikator tersebut dalam penelitian ini terlihat dari kemampuan siswa dalam menjelaskan hasil pengamatan yang telah dilakukan. Berdasarkan hasil analisis data nilai posttest dan nilai pretest kedua kelas, diketahui kelas kontrol lebih unggul dari kelas eksperimen. Secara keseluruhan, kedua kelas mengalami peningkatan keterampilan berpikir kritis pada indikator mempertimbangkan laporan observasi yang dapat dilihat dari nilai $\mathrm{N}$-Gain kedua kelas. Nilai $N$-Gain yang dihasilkan siswa kelas eksperimen dan kelas kontrol masuk dalam kategori sedang.

Setelah dilakukan uji hipotesis dengan uji Mann Whitney terhadap nilai N-Gain keterampilan berpikir kritis pada indikator mengobservasi dan mempertimbangkan laporan observasi, harga signifikansi yang diperoleh sebesar 0,875 yang lebih besar dari 0,05 (p > 0.05). Hasil tersebut menunjukkan bahwa tidak ada perbedaan peningkatan keterampilan berpikir kritis pada indikator mengobservasi dan mempertimbangkan laporan observasi antara siswa kelas eksperimen dan kelas kontrol. Hal ini mengindikasikan bahwa tidak ada pengaruh model pembelajaran discovery learning terhadap peningkatan keterampilan berpikir kritis siswa pada indikator mengobservasi dan mempertimbangkan laporan observasi. Hal tersebut terjadi karena siswa lebih sering menghafal materi yang dipelajari tanpa memahami konsep. Hal ini didukung oleh pernyataan Ariyati (2010), bahwa pembelajaran di sekolah lebih banyak menghafal.

Pembelajaran dengan menghafal tidak menuntut siswa untuk melaporkan hasil observasi terlebih dahulu sebelum memberikan inti jawaban. Indikator mengobservasi dan mempertimbangkan laporan observasi mengalami peningkatan tertinggi pada kelas eksperimen dan kelas kontrol. Siswa kelas eksperimen dan kelas kontrol telah mampu mengobservasi dan mempertimbangkan laporan observasi yaitu dengan menjelaskan hasil pengamatan yang telah diperoleh dari percobaan kemudian menguhubungkan hasil pengamatan tersebut dengan sub materi pokok yang dipelajari. Hal ini didukung oleh pernyataan Sukmana (2008), bahwa peningkatan kemampuan berpikir kritis dapat dilakukan melalui kegiatan praktikum dan pengamatan secara langsung. Kedua kelas 
melakukan percobaan yang sama, oleh karena itu pencapaian indikator tersebut hanya sedikit berbeda yang dapat dilihat dari selisih $\mathrm{N}$-Gain yang diperoleh pada indikator ini yaitu 0,02 .

\section{Menentukan Suatu Tindakan}

Menentukan suatu tindakan merupakan salah satu indikator keterampilan berpikir kritis yang termasuk kedalam kelompok mengatur strategi dan taktik. Berdasarkan hasil analisis data nilai posttest dan nilai pretest kedua kelas, kelas kontrol lebih unggul dari kelas eksperimen. Secara keseluruhan, kedua kelas mengalami peningkatan keterampilan berpikir kritis pada indikator menentukan suatu tindakan yang dapat dilihat dari nilai $\mathrm{N}$ Gain kedua kelas. Setelah dilakukan uji hipotesis dengan uji-t terhadap nilai $N$-Gain keterampilan berpikir kritis pada indikator menentukan suatu tindakan, harga signifikansi yang diperoleh sebesar 0,319 yang lebih besar dari $0,05(\mathrm{p}>0.05)$. Hasil tersebut menunjukkan bahwa tidak ada perbedaan peningkatan keterampilan berpikir kritis pada indikator menentukan suatu tindakan antara siswa kelas eksperimen dan kelas kontrol. Hal ini mengindikasikan bahwa tidak ada pengaruh model pembelajaran discovery learning terhadap peningkatan keterampilan berpikir kritis siswa pada indikator menentukan suatu tindakan. Hal tersebut terjadi karena siswa lebih sering menghafal materi yang dipelajari tanpa memahami konsep. Hal ini didukung oleh pernyataan Ariyati (2010), bahwa pembelajaran di sekolah lebih banyak menghafal.

Pembelajaran dengan menghafal tidak menuntut siswa untuk memberikan tindakan awal terlebih dahulu sebelum memberikan inti jawaban. Faktor lain dikarenakan juga karena kemampuan awal siswa yang berbeda, dimana nilai pretest siswa kelas kontrol pada indikator ini lebih tinggi dari kelas eksperimen. Hal ini didukung oleh pernyataan Praptiwi (2012). Kemampuan awal akan mempengaruhi berhasil atau tidaknya seorang siswa dalam pembelajaran. Jika kemampuan awal siswa baik, maka siswapun akan memperoleh hasil yang baik.

\section{Menginduksi}

Menginduksi merupakan salah satu indikator keterampilan berpikir kritis yang temasuk dalam kelompok menyimpulkan. Hasil analisis nilai posttest dan nilai pretest kedua kelas menunjukkan bahwa kelas kontrol lebih unggul dibandingkan kelas eksperimen. Secara keseluruhan, kedua kelas mengalami peningkatan keterampilan berpikir kritis pada indikator menginduksi yang dapat dilihat dari nilai $\mathrm{N}$-Gain kedua 
kelas. Setelah dilakukan uji hipotesis dengan uji Mann Whitney terhadap nilai N-Gain keterampilan berpikir kritis indikator menginduksi, harga signifikansi yang diperoleh sebesar 0,515 yang lebih besar dari 0,05 ( $\mathrm{p}>0.05)$. Hasil tersebut menunjukkan bahwa tidak ada perbedaan peningkatan keterampilan berpikir kritis pada indikator menginduksi antara siswa kelas eksperimen dan kelas kontrol. Hal ini mengindikasikan bahwa tidak ada pengaruh model pembelajaran discovery learning terhadap peningkatan keterampilan berpikir kritis siswa pada indikator menginduksi.

Hal tersebut terjadi karena siswa lebih cenderung hanya memberikan jawaban tanpa memberikan kesimpulan. Menurut Ardiyanti (2013), dengan membiasakan siswa untuk menyimpulkan maka siswa akan terlatih membuat kesimpulan. Faktor lain dikarenakan juga karena kemampuan awal siswa yang berbeda, dimana nilai pretest siswa kelas kontrol pada indikator ini lebih tinggi dari kelas eksperimen. Hal ini didukung oleh pernyataan Praptiwi (2012). Kemampuan awal akan mempengaruhi berhasil atau tidaknya seorang siswa dalam pembelajaran. Jika kemampuan awal siswa baik, maka siswapun akan memperoleh hasil yang baik.

\section{Mengidentifikasi Asumsi}

Mengidentifikasi asumsi merupakan salah satu indikator keterampilan berpikir kritis yang termasuk dalam kelompok memberikan penjelasan lanjut. Hasil analisis data nilai posttest dan nilai pretest diketahui bahwa kelas eksperimen lebih meningkat dari kelas kontrol. Secara keseluruhan, kedua kelas mengalami peningkatan keterampilan berpikir kritis pada indikator mengidentifikasi asumsi yang dapat dilihat dari nilai $N$-Gain kedua kelas. Nilai $N$-Gain yang dihasilkan kedua kelas masuk dalam kategori rendah. Setelah dilakukan uji hipotesis dengan uji - $t$ terhadap nilai $N$-Gain keterampilan berpikir kritis pada indikator mengidentifikasi asumsi, harga signifikansi yang diperoleh sebesar 0,061 yang lebih besar dari $0,05(p>0.05)$. Hasil tersebut menunjukkan bahwa tidak ada perbedaan peningkatan yang signifikan keterampilan berpikir kritis pada indikator mengidentifikasi asumsi antara siswa kelas eksperimen dan kelas kontrol. Hal ini mengindikasikan bahwa tidak ada pengaruh model pembelajaran discovery learning terhadap peningkatan keterampilan berpikir kritis siswa pada indikator mengidentifikasi asumsi. Hal ini disebabkan karena siswa kurang memahami konsep-konsep dalam materi hidrokarbon dengan baik sehingga kurang dapat mengidentifikasi asumsi. Hal ini 
didukung oleh pernyataan Poedjadi dalam Lambertus (2009), bahwa untuk dapat berpikir kritis maka siswa harus menguasai konsep.

\section{KESIMPULAN DAN SARAN}

Berdasarkan hasil penelitian dapat disimpulkan bahwa tidak terdapat perbedaan peningkatan keterampilan berpikir kritis antara siswa kelas eksperimen dan kelas kontrol pada masing-masing indikator. Bagi penliti selanjutnya diharapkan memperhatikan karakteristik peserta didik dengan baik sebelum menggunakan sebuah model pembelajaran agar mendapatkan hasil yang maksimal.

\section{DAFTAR PUSTAKA}

Alfieri, L. Brooks, Patricia J. Aldrich, Naomi J \&Tenenbaum, H. 2011. Does DiscoveryBased Instruction Enhance Learning?. Journal of Educational Psychology. Vol 103(1):1-18.

Ardiyanti, Farida. 2013. Pengaruh Model Pembelajaran Berbasis Fenomena untuk Meningkatkan Ketermpilan Berpikir Kritis Sisw Sekolah Dasar. Kaunia. Vol IX(2): 27-33.

Ennis, R. H. 1985. Goals for Critical Thinking Curriculum, In A.L. Costa, Developing Minds: A Resource Book for Teaching Thinking. Alexandria: Association for Supervisor and Curriculum Development (ASCD).

Hasruddin. 2009. Memaksimalkan Kemampuan Berfikir Kritis Melalui Pendekatan Kontekstual. Jurnal Tabularsa PPS UNIMED: Vol 6(1):48-60.

Lambertus. 2009. Pentingnya Melatih Keterampilan Berfikir Kritis dalam Pembelajaran Matematika di SD. Jurnal forum Kependidikan. Vol 28(2):136-142.

Nitko, A.J. 1996. Educational Assesment of Student. Englewuood Cliffs: Merril Norris, S.P. dan Ennis, R. 1989. Evaluating Critical Thinking ( dalam R. J. Schwartz \& D. N. Perkins (Eds), The Practitioners' Guide to Teaching Thinking Series. Pacific Grove, California: Midwest Publications.

Peter, E.E. 2012. Critical Thinking: Essence for Teaching Mathematics and Mathematics Problem Solving Skills. African Journal of Mathematics and Computer Science Research. Vol 5(3):39-43. 
Sastrika, IK. Sadia, IW \& Muderawan, IW. 2013. Pengaruh Model Pembelajaran Berbasis Proyek terhadap Pemahaman Konsep Kimia dan Keterampilan Berpikir Kritis. $e$ Journal Program Pascasarjana Universitas Pendidikan Ganesha: Vol 3.

Suriadi. 2006. Pembelajaran dengan Pendekatan Discovery yang Menekankan Aspek Analogi Untuk Meningkatkan Pemahaman Matematik dan Kemampuan Berpikir Kritis Siswa SMA. Tesis pada PPs UPI. Tidak dipublikasikan. 